\title{
Percepção local acerca da aplicabilidade do Ecoturismo de Base Comunitária na RESEX Corumbau (BA)
}

\section{Local perception about the applicability of Community Based Ecotourism at RESEX Corumbau (BA, Brazil)}

\author{
Zysman Neiman, Juliana Maria de Barros-Freire
}

RESUMO: A Reserva Extrativista (RESEX) Corumbau foi criada no ano de 2000, está localizada na região do extremo-sul do Estado da Bahia é considerada uma área de extrema importância para conservação ambiental, devido a sua proximidade com a zona de maior biodiversidade marinha do Atlântico Sul. A inserção do turismo, que ocorre na região desde os anos de 1970 , tem ocasionado a substituição das atividades tradicionais, como no caso da pesca artesanal, e da agricultura de subsistência. Uma alternativa que se vislumbra para a região é a implementação do Ecoturismo de Base Comunitária. No presente estudo foram realizadas 3 oficinas em Cumuruxatiba, Corumbau, e Bujigão-Caraíva, cada uma com 3 momentos didáticos distintos, nos quais foram recolhidos dos participantes os principais aspectos culturais e ambientais, elaborado de forma participativa, que permitiu identificar o que a comunidade tem a oferecer como atrativos, suas relevâncias e diferenciais. Utilizando-se da metodologia de análise de conteúdo, foi possível observar e agrupar as 7 principais categorias de percepção dos comunitários: a) impactos do turismo sobre o patrimônio natural, com a extração indevida de recursos das unidades de conservação; b) questão fundiária e disputa por território; c) "invasão" de empreendedores e visitantes externos às comunidades; d) desunião dos comunitários e individualismo nas relações de trabalho com o turismo. e) manutenção das culturas locais, com forte enraizamento e desejo de resgate e manutenção de modos de vida e cultura ancestrais; f) fraqueza nos arranjos institucionais formais; e g) potencialidade de parcerias com outros segmentos. Por fim, o levantamento de caráter exploratório, revelou os atrativos mais relevantes da RESEX do ponto de vista das comunidades.

PALAVRAS CHAVE: Economia Solidária; Sustentabilidade; Ecoturismo de Base Comunitária. 
ABSTRACT: The Corumbau Extractive Reserve was created in the year 2000, is located in the extreme southern region of the state of Bahia (Brazil)and is considered an area of extreme importance for the conservation environmental due to its proximity to greater marine biodiversity of the South Atlantic. The insertion of tourism, which occurs in the region since the 1970s, caused the replacement of traditional activities, such as artisanal fishing and subsistence agriculture. An alternative that is envisioned for the Region and implementation of Community Based Tourism (CBT). In the present study, 3 CBT workshops were held in Cumuruxatiba, Corumbau and Bujigão-Caraíva, each with 3 distinct moments, in which were collected of the participants the main cultural and environmental themes, participatively reported, which allowed us to identify what the community has to offer as attractions, their relevance and differentials. Using the content analysis methodology, it was possible to observe and group the 7 main categories of community perception: a) impacts on tourism on the natural heritage, with improper extraction of resources from protected areas; b) land problems and dispute over territory; c) "invasion" of entrepreneurs and visitors from outside the communities; d) disunity of residents and individualism in labor relations with tourism. e) maintenance of local cultures, with strong roots and desire to rescue and maintain ancestral ways of life and culture; f) weakness in formal institutional arrangements; and g) potentiality of partnerships with other segments. Finally, the exploratory survey revealed the most relevant attractions of Extractive Reserve from the point of view of communitarians.

KEYWORDS: Solidarity Economy; Sustainability; Community Based Tourism.

\section{Introdução}

Maldonado (2009) afirma que o Turismo de Base Comunitária (TBC) iniciou recentemente na América Latina, sendo as primeiras incursões a comunidades isoladas datadas de meados dos anos 1980. Em território brasileiro, de acordo com Sansolo e Bursztyn, (2009), é a partir da década de 1990 que o turismo passa a ser uma atividade não agrícola que agrega valor às atividades de agricultores familiares.

Para Maldonado (2009), diversos fatores estão associados à origem do TBC na América Latina, tais como: pressões mundiais do mercado turístico; busca de superação de pobreza crônica por algumas comunidades; papel relevante das pequenas e microempresas no desenvolvimento econômico local e na diversificação da oferta turística; e as estratégias políticas do movimento indígena e rural para preservar seus territórios ancestrais na ótica de incorporação aos processos de globalização com sua própria identidade.

Debruçados também sobre o estudo do TBC sob o ponto de vista conceitual em diversos países latino-americanos, Sansolo e Bursztyn, (2009, p. 147) observam que "os componentes de conservação ambiental e valorização da identidade cultural sustentam esta proposta de turismo, bem como a geração de benefícios diretos para as comunidades receptoras". Para os autores, esses benefícios viriam da organização e controle da atividade por parte da comunidade.

Em consonância com essa ideia, porém em uma perspectiva mais social, Irving (2009, p. 111) analisa que "o Turismo de Base Comunitária (TBC), portanto, tende a ser aquele tipo de turismo que, em tese, favorece a coesão e o laço social e o sentido coletivo de vida em sociedade, e que por esta via, promove a qualidade de vida, o sentido de inclusão, a valorização da cultura local e o sentimento de pertencimento".

Deste modo, sem contrapor o conceito apresentado por Sansolo e Bursztyn, (2009), a definição de Irving (2009) ressalta aspectos relacionados com a coesão 
social, remarcando que ${ }_{2}$ antes de tudo, esse tipo de turismo é assim designado não porque ocorre em uma comunidade enquanto é visitada por turistas, mas porque surge de algo comum, de algo coletivo.

Ainda de acordo com Irving (2009), algumas premissas centrais emergem na releitura sobre o TBC: base endógena da iniciativa e desenvolvimento local; participação e protagonismo social no planejamento, implementação e avaliação de projetos turísticos; escala limitada e impactos sociais e ambientais controlados; geração de benefícios diretos à população local; afirmação cultural e interculturalidade; e o "encontro" como condição essencial. Ou seja, é necessário a percepção de benefícios pelas comunidades a partir da atividade, geralmente traduzidos em geração de renda.

De acordo com informações obtidas junto a Redturs - Red de Turismo Comunitario de America Latina, atualmente existem 322 destinos comunitários em toda a América Latina. No Brasil, são 37, sendo que o país fica atrás apenas do Equador, que possui 52 destinos dessa natureza.

Nas propostas de organização do Ecoturismo de Base Comunitária1, é comum que as comunidades recorram a agentes externos que possam colaborar com esse processo, como o poder público, o setor privado e as organizações do terceiro setor. Importante destacar que existem várias possibilidades de as comunidades participarem e/ou desenvolverem a atividade turística. Nesse sentido, Maldonado (2009) sistematiza a participação das comunidades no que chama de "indústria do turismo" em seis modalidades (Quadro 1):

Quadro 1: Participação das comunidades no turismo e suas principais características.

Table 1: Community participation in tourism and its main characteristics.

\begin{tabular}{|l|l|}
\hline \multicolumn{1}{|c|}{ Modo de participação } & \multicolumn{1}{|c|}{ Principais características } \\
\hline $\begin{array}{l}\text { 1) Autogestão do } \\
\text { negócio turístico }\end{array}$ & $\begin{array}{l}\text { A comunidade decide trabalhar com turismo em seu território, } \\
\text { participa de todas as etapas: planejamento, execução, } \\
\text { promoção/venda dos produtos e gestão }\end{array}$ \\
\hline $\begin{array}{l}\text { 2) Parceria de negócios } \\
\text { com uma empresa } \\
\text { privada }\end{array}$ & $\begin{array}{l}\text { Há um contrato legal por tempo determinado entre investidor e } \\
\text { comunidade, existe repartição de benefícios e obrigações e, ao } \\
\text { final, o contrato pode ser renovado ou não }\end{array}$ \\
\hline $\begin{array}{l}\text { 3) Parceria comercial } \\
\text { com operadoras de } \\
\text { turismo }\end{array}$ & $\begin{array}{l}\text { Existe um acordo onde a agência envia turistas e a comunidade } \\
\text { os recebe, presta serviços, é remunerada por isso, e muitas } \\
\text { vezes recebe apoio da empresa para capacitação e } \\
\text { infraestrutura, mas esta controla o fluxo }\end{array}$ \\
\hline $\begin{array}{l}\text { 4) Concessão de } \\
\text { recursos comunitários } \\
\text { em usufruto }\end{array}$ & $\begin{array}{l}\text { As comunidades cedem para uso temporário os recursos naturais } \\
\text { de seu território e alguns serviços culturais em troca de benefícios } \\
\text { acordados com empresas de turismo }\end{array}$ \\
\hline $\begin{array}{l}\text { 5) Trabalho assalariado } \\
\text { para operários }\end{array}$ & $\begin{array}{l}\text { Algumas famílias participam a título pessoal do apoio à realização } \\
\text { de turismo na região (fora da comunidade) em troca de } \\
\text { remuneração e em caráter temporário, não existindo projeto } \\
\text { comunitário }\end{array}$ \\
\hline 6) Formas híbridas & $\begin{array}{l}\text { Agências levam turistas para a comunidade e ao mesmo tempo } \\
\text { contratam esta para prestação de serviços. A comunidade realiza } \\
\text { investimentos próprios. Há um sistema de rodízio para que todos } \\
\text { os membros da comunidade interessados possam ser } \\
\text { contratados }\end{array}$ \\
\hline
\end{tabular}

Fonte: Elaborado a partir de dados de Maldonado (2009).

Source: Based on data from Maldonado (2009). 


\section{A Reserva Extrativista Marinha do Corumbau}

A RESEX Corumbau foi criada no ano de 2000 , a partir de uma ação coletiva dos pescadores locais, que obtiveram apoio de órgãos governamentais, como a Coordenação Nacional de Populações Tradicionais (CNPT) e de entidades ambientalistas do terceiro setor como a Associação Pradense de Proteção Ambiental (APPA), e posteriormente a Conservation International do Brasil (ClBrasil) (Carvalho \& Knox, 2014). Localizada na região do extremo-sul do Estado da Bahia (Figura 1) é considerada uma área de extrema importância para conservação da biodiversidade marinha, devido a sua proximidade à "Região dos Abrolhos" e à presença de significativos recifes coralinos, compondo a zona de maior biodiversidade do Atlântico Sul. Tem como principal característica o fato de não incluir a parte terrestre, senão apenas a área sob influência das águas. Isso representa um problema para as comunidades locais, uma vez que as mesmas se encontram na da Zona de Amortecimento, o que gera limitações ao seu direito de posse das terras.

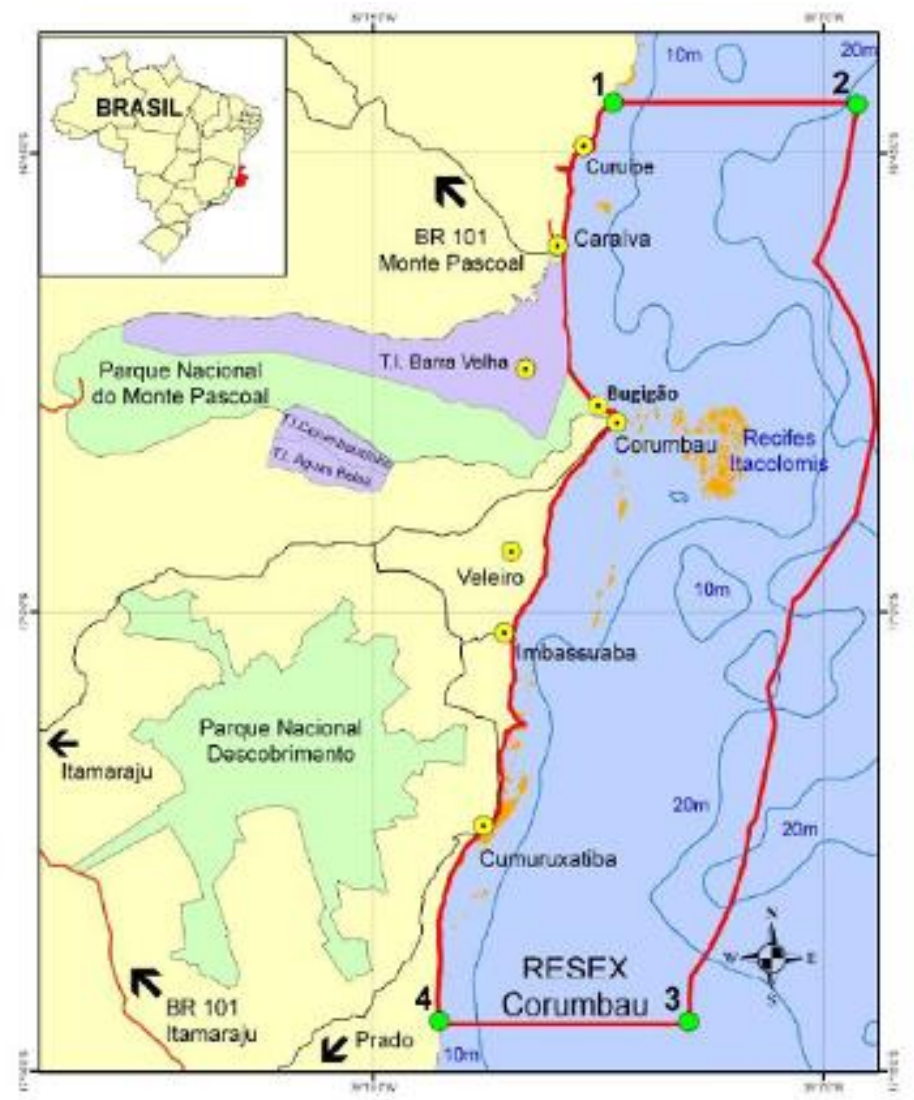

Figura 1: Localização da RESEX Corumbau. Fonte: Carvalho e Knox (2014). Figure 1: Location of RESEX Corumbau. Source: Carvalho and Knox (2014).

Tal região, denominada "Costa do Descobrimento" (Porto Seguro, BA) e "Costa das Baleias (Prado, BA), caracteriza-se como o segundo polo turístico do Estado de Bahia (o primeiro é Salvador, usando como critério o número de turistas), contando com atrativos naturais, além de aspectos históricos e culturais e com forte presença de setores econômicos que suportam a atividade turística. Como exemplo, pode-se destacar que o setor de hotelaria sofreu um crescimento de $6 \%$ ao ano, no período de 1974 a 2000. 
Devido a esse aumento, existe uma pressão demográfica forte, o que sugere que o crescimento do número de turistas não deve ser incentivado na região. Há necessidade urgente de investimentos no tocante ao retorno de resíduos à natureza, fonte da contaminação e poluição ambiental (FARIA, 2007).

A comunidade residente na RESEX Corumbau, formada majoritariamente por indígenas e descendentes da etnia Pataxó, é composta por cerca de 850 famílias beneficiárias que tem na pesca artesanal tradicional sua principal base econômica e cultural, apesar da atividade turística já ter papel significativo na composição da renda familiar de alguns de seus moradores. São quatro vilas principais que já apresentam significativa infraestrutura turística e representam destinos turísticos consolidados: Cumuruxatiba e Corumbau (Prado), Caraíva e Curuípe (Porto Seguro). As demais localidades da RESEX apresentam potencial para a implantação do Ecoturismo de Base Comunitária.

A inserção do turismo, que ocorre na região desde os anos de 1970, tem ocasionado a substituição das atividades tradicionais, como no caso da pesca artesanal, pois os mais jovens têm optado por se tornarem trabalhadores assalariados nos meios de hospedagem que proliferam na região (ESPÍNOLA; ANDRADE, 2015), e da agricultura de subsistência, substituída pelo trabalho como guias de turismo (LOZADA, 2017).

A dinâmica da atividade turística, portanto, tem impactado tanto positiva, quanto negativamente a cultura e a sustentabilidade ambiental dessas comunidades, o que impõe um necessário fortalecimento da sua identidade como uma premissa para o desenvolvimento local, importando aos indivíduos dessa comunidade se reconhecerem e "assumirem esse eficaz instrumento com o objetivo de se tornar protagonista do seu próprio processo de desenvolvimento local" (KASHIMOTO et al., 2002 , p. 39). O crescimento da atividade turística tem ameaçado, inclusive, a sustentabilidade dos recursos naturais da Unidade de Conservação, bem como a valorização da identidade local (BACAL; MIRANDA, 1997).

Uma alternativa que se vislumbra para a Região é a implementação do Ecoturismo de Base Comunitária, uma vez que esta forma de gestão do turismo dialoga de maneira mais coerente com o propósito de criação das Reservas Extrativistas. Esta categoria de Unidade de Conservação de Uso Sustentável está prevista na Lei 9.985/2000 (SNUC) e se destina a proteger os meios de vida e a cultura das populações extrativistas tradicionais e, no particular, quanto à RESEX Corumbau, a "garantir a exploração autossustentável e a conservação dos recursos naturais renováveis tradicionalmente utilizados pela população extrativista da área" (art. 2ํㅡㄹ Decreto de 21/19/2000).

Atualmente, a RESEX Corumbau está em fase final de elaboração de seu Plano de Manejo e este instrumento prevê a atividade do Ecoturismo de Base Comunitária como uma alternativa de incremento da renda da população extrativista beneficiária, atrelada ao fortalecimento e valorização da cultura tradicional, ao uso sustentável dos recursos e a conservação da UC.

Alguns aspectos observados na RESEX Corumbau apontam para seu potencial para o TBC. Os indígenas da etnia Pataxó, predominante na região, "foram se estabelecendo próximo aos dois municípios que estavam em plena fase de crescimento impulsionado pela atividade turística; e encontraram no turismo uma alternativa para seu sustento" (FREITAS; MATTOS, 2009, p. 120). Por meio de sua cultura, começaram a confeccionar e vender artesanato e aos poucos foram se 
configurando como mais um atrativo turístico da região. O ritual do Awê é considerado o único ritual tradicional entre os Pataxó Meridionais (NEVES, 2010). Os Pataxó ensaiam e realizam a exibição de suas tradições para públicos externos às suas comunidades indígenas, mediante alguma espécie de troca com a parte que os contrata para a encenação (GRÜNEWALD, 2000).

Algumas manifestações culturais que traduzem a herança cultural ainda estão razoavelmente preservadas. Entretanto, muitas outras sofrem a comercialização como produto turístico e, no caso dos extrativistas, o turismo tem gerado mudanças visíveis. Os dados sinalizam para a consolidação turística, com a instalação de equipamentos como pousadas, hotéis, restaurantes, barracas de praia, e demais atividades do comércio e serviços. Isso pode provocar um sentimento de esfacelamento e perda do modo de vida comunitário, em que as famílias dos extrativistas da RESEX se reconheciam, construindo um dos impactos negativos do desenvolvimento turístico. Apesar da geração de emprego e renda ser a principal vantagem, outros problemas, podem ainda ocorrer com a chegada do turismo de massa: a degradação ambiental; a poluição sonora; a produção excessiva de lixo; o crescimento desordenado; a geração de empregos informais; a mudança nos costumes e valores; entre outras.

Os equipamentos, comércio e serviços locais, direcionados para o turismo, enfrentam o problema da sazonalidade, que afeta a estabilidade financeira dos moradores. Na baixa estação, muitos restaurantes, pousadas e lojas fecham as portas ou se mantêm com baixo índice de atividade, causando falta de trabalho para os locais.

Uma gestão participativa do Ecoturismo de Base Comunitária, por levar em conta os aspectos sociais, culturais e ambientais da RESEX, pode promover a inclusão da população local na concepção do planejamento e organização da atividade, contribuindo para reduzir os impactos provenientes do desenvolvimento da atividade turística. É nesse contexto que se realizou este estudo, que passamos a relatar.

\section{Metodologia}

Antes de ser iniciada, a pesquisa que resultou no presente relatório foi submetida à Comissão de Ética da Universidade Federal de São Paulo, aprovada com número de protocolo 08917219.0.0000.5505, e ao Sistema de Autorização e Informação em Biodiversidade do Instituto Chico Mendes de Conservação e Biodiversidade (SISBIO/ICMBio), aprovada em 24/04/2019 com o número de protocolo 69062-1, além da produção do Termo de Consentimento Livre Esclarecido (TCLE) e Autorização para Uso da Imagem dos participantes da pesquisa.

Os pesquisadores participaram, em seguida, da Oficina de Elaboração do Plano de Manejo da RESEX, realizada entre os dias 05 a 07 de abril de 2019. Para fazer um reconhecimento da realidade local, os pesquisadores fizeram levantamentos de campo entre os dias 28 de março e 10 de abril, incluído aqui o período de participação na Oficina de Plano de Manejo.

$\mathrm{Na}$ Oficina de Plano de Manejo participaram as maiores lideranças das comunidades da RESEX, com as quais houve diálogos preliminares para os primeiros levantamentos. Durante as Oficinas do Plano de Manejo, a equipe de pesquisadores solicitou a palavra para anunciar como seriam realizadas oficinas de TBC e fazer pedidos às lideranças presentes para que convidassem e organizassem 
a participação de comunitários interessados nessa temática, anunciando que seriam abertas 10 vagas para cada uma das comunidades beneficiárias na RESEX.

As negociações com a equipe do ICMBio e comunitários permitiu a elaboração do cronograma de trabalho com a realização de 3 oficinas de TBC: Cumuruxatiba, Corumbau, e Bujigão-Caraíva, que ocorreram, respectivamente, na Associação dos Pescadores de Cumuruxatiba (APEC), na Escola Municipal de Corumbau, e na Associação dos Nativos de Caraíva (ANAC).

Com relação ao projeto pedagógico das oficinas, ficou acordado que elas teriam 3 momentos didáticos distintos. No primeiro bloco, com duração de 4 horas correspondentes à manhã do primeiro dia, quatro questões apresentadas aos participantes foram norteadoras para a coleta de suas percepções e comentários:

1)Como está ocorrendo o "Turismo" na RESEX Corumbau?

2)Quais atividades, mesmo que não ligadas ao Turismo, vocês já realizam coletivamente nas comunidades?

3)O que você entende por "Ecoturismo de Base Comunitária"?

4)Quais atrativos ambientais e culturais vocês entendem como o diferencial da RESEX?

Os debates, que se derem no modelo "Roda de Conversa" (Grupo Focal), buscaram diagnosticar as percepções dos participantes sobre o conceito e as potencialidades do TBC, além de permitir um primeiro levantamento de atrativos que possam ser utilizados por essa atividade. A mediação dos Grupos Focais foi realizada pelos pesquisadores. Todos os debates foram gravados com autorização prévia dos participantes, para posterior transcrição das informações mais relevantes e análise do conteúdo dos depoimentos, de modo a categorizar as principais percepções, conflitos, potencialidades e propostas.

Concluída essa primeira etapa, e a partir do diagnóstico realizado, em cada oficina foi apresentado, de forma mais sistematizada, os principais conceitos relativos ao Ecoturismo de Base Comunitária, explorando aspectos apontados pelos participantes no primeiro momento, e aprofundando, por meio de uma palestradialogada, cada tema de interesse do grupo.

O terceiro e último bloco das oficinas de TBC, foi realizado por meio da visita a alguns atrativos turísticos da RESEX, indicados pelos próprios comunitários, foram recolhidos depoimentos sobre eles, bem como diversos aspectos relevantes trazidos por cada participante (Figura 2).

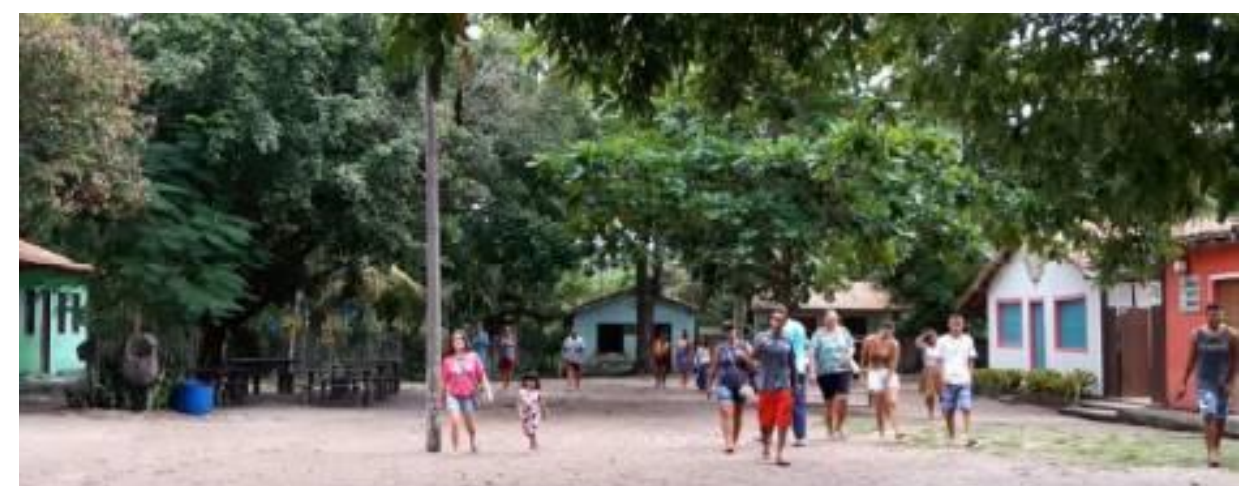

Figura 2: Participantes em atividades de campo. Fonte: foto de Zysman Neiman (2019).

Figure 2: Participants in field activities. Source: photo by Zysman Neiman (2019). 
Esses depoimentos foram registrados em vídeo, com autorização dos participantes e, além de compor acervo documental para as comunidades e gestores da RESEX, foi organizado e editado pelos pesquisadores em formato de um pequeno curta-metragem para usos de divulgação.

Com os elementos recolhidos, tanto no primeiro, quanto no terceiro blocos das oficinas, foi possível a conclusão de um levantamento dos principais aspectos culturais e ambientais, elaborado de forma participativa, que permitiu identificar o que a comunidade tem a oferecer como atrativos, suas relevâncias e diferenciais, procurando categorizar e estabelecendo quais seus potenciais mercados-alvo.

No total, inscreveram-se 95 participantes, assim distribuídos: 26 na oficina de Cumuruxatiba, 32 na oficina de Corumbau e 37 na oficina de Caraíva (Figura 3).
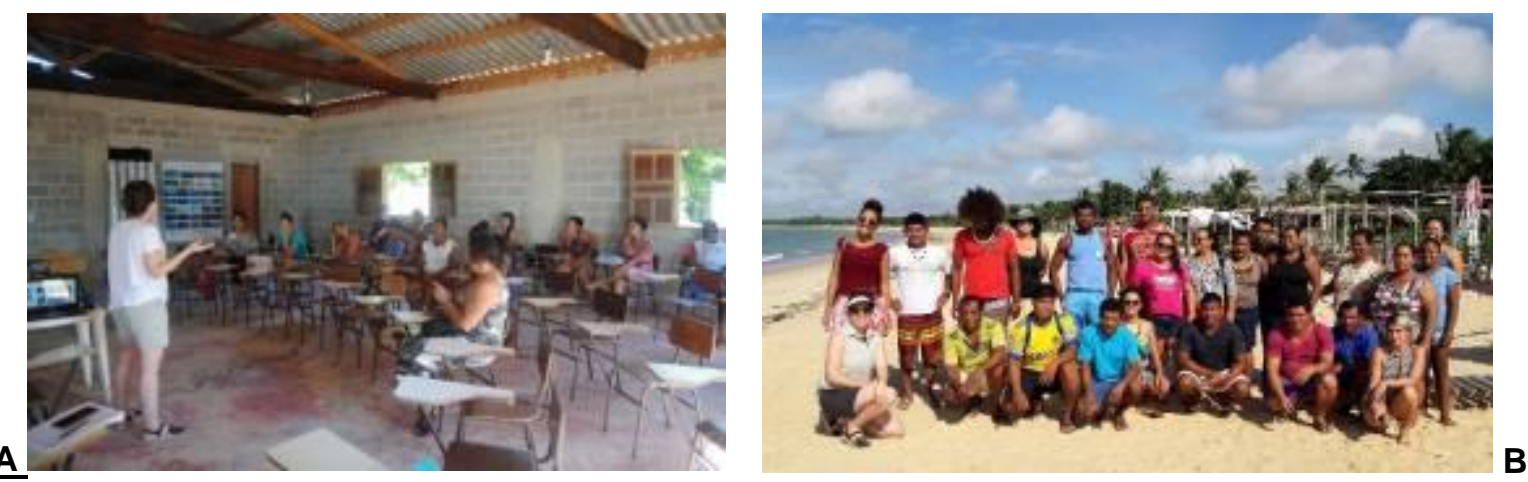

Figura 3: Imagens das Oficinas de TBC. Fonte: fotos de Zysman Neiman (2019).

Figure 3: Images from TBC workshops. Source: photos by Zysman Neiman (2019).

\section{Resultados e Discussão}

\section{Diagnóstico realizado}

O objetivo maior deste estudo foi apresentar os resultados da mobilização, capacitação, e construção dialógica de uma percepção local sobre o significado e aplicabilidade do Ecoturismo de Base Comunitária na RESEX Corumbau. Desta forma, tanto o primeiro como o terceiro bloco das oficinas foram fundamentais.

Com base nas perguntas norteadoras feitas no primeiro bloco, foi possível estabelecer um diálogo entre os pesquisadores e os participantes e entre os comunitários, entre si, de modo semiestruturado, obtendo-se, com isso, um diagnóstico participativo através dos relatos e percepções.

A primeira pergunta que abriu o debate foi: "Vamos Falar sobre Turismo?". Esse momento, permitiu que os comunitários se expressassem sobre a atividade de turismo que já praticam ou que observam em seu território, os atuais desafios e pressões que enfrentam em sua condição de extrativistas, as principais queixas e dificuldades nos aspectos ambiental, social, econômico e institucionais em que são afetados direta ou indiretamente pelo turismo. Essas questões são importantes para a compreensão do ambiente e os impactos que pesam sobre ele, no sentido de analisar a viabilidade da aplicação do Ecoturismo de Base Comunitária no território.

A pergunta sobre "o que fazem coletivamente?", procurou obter as percepções da força e engajamento da comunidade nas questões coletivas e o grau de união e articulação que já possuem, elementos fundamentais que norteiam qualquer projeto de Ecoturismo de Base Comunitária. Nesse debate, boa parte dos 
relatos ressaltou as dificuldades de união que hoje as comunidades enfrentam, mas também houve falas onde se percebeu um forte desejo de resgate das tradições, cultura e modos de vida ancestrais para fazer disso um diferencial na construção de uma atividade turística que gere maiores benefícios para os comunitários.

A pergunta sobre "Ecoturismo de Base Comunitária - Do que Estamos Falando?", visou perceber o que os participantes já conheciam sobre essa forma de gestão do turismo e quais as questões relevantes sobre os potenciais com relação aos atrativos turísticos que valorizem a cultura e tradições das comunidades.

A última pergunta, "Que encantos ambientais e culturais vocês têm para mostrar?", visou realizar um primeiro diagnóstico participativo dos atrativos locais, completado com o terceiro bloco das oficinas.

Tendo sido realizada a degravação de todos os depoimentos, e utilizando-se da metodologia de análise de conteúdo, foi possível observar e agrupar as principais categorias de percepção dos comunitários. Aparentemente, do agrupamento das falas, houve como definir 7 categorias (temas) mais importantes (Quadro 2), descritas adiante (todas exemplificadas com trechos de falas dos participantes).

Quadro 2: Categorias de percepções (temas) recolhidas dos depoimentos.

Table 2: Categories of perceptions (themes) collected from the statements.

\begin{tabular}{|c|l|}
\hline Aspectos & \multicolumn{1}{|c|}{ Categorias (Temas) } \\
\hline \multirow{2}{*}{ Ambientais } & $\begin{array}{l}\text { impactos do turismo sobre o patrimônio natural, com a extração indevida de recursos } \\
\text { das unidades de conservação. }\end{array}$ \\
\hline \multirow{2}{*}{ Econômicos } & questão fundiária e disputa por território. \\
\cline { 2 - 2 } & "invasão" de empreendedores e visitantes externos às comunidades. \\
\hline \multirow{2}{*}{ Sociais } & desunião dos comunitários e individualismo nas relações de trabalho com o turismo. \\
\cline { 2 - 2 } & $\begin{array}{l}\text { manutenção das culturas locais, com forte enraizamento e desejo de resgate e } \\
\text { manutenção de modos de vida e cultura ancestrais. }\end{array}$ \\
\hline \multirow{2}{*}{ Institucionais } & fraqueza nos arranjos institucionais formais. \\
\cline { 2 - 2 } & potencialidade de parcerias com outros segmentos. \\
\hline
\end{tabular}

Os nomes dos depoentes foram mantidos em sigilo para preservar os mesmos de eventuais constrangimentos, sendo apresentados por números juntamente aos códigos referentes a oficina da qual participaram: $\mathrm{X}$ - Cumuruxativa, B - Corumbau, V - Caraíva.

Todo o trecho a seguir, que descreve as categorias, foi construído a partir dos depoimentos recolhidos e referem-se unicamente às afirmações dos comunitários.

\section{Impactos do turismo sobre o patrimônio natural, com a extração indevida de recursos das Unidades de Conservação}

Ambientalmente, há desafios importantes provocados pelo turismo, que vêm impactando a fauna marinha, como a morte de caranguejos e desaparecimento de peixes, como a garoupa, por exemplo, trazendo redução da fonte de subsistência dos extrativistas. Além disso, o pisoteamento em recifes de coral durante atividades de mergulho tem afetado diretamente a biodiversidade desses sistemas. 
Foi relatado que está em curso a construção de uma barragem no Rio Cahy, e os gestores do Parque Nacional do Monte Pascoal já estão verificando, pois o impacto pode ser grande. É importante que haja uma luta de toda a RESEX para impedir a construção dessa barragem. A questão dos recursos hídricos é fundamental, pois é a fonte de vida para muitas famílias de pescadores e extrativistas.

A questão do lixo também é um problema grave que foi mencionado em todas as oficinas. Uma proposta surgida foi a colocação placas de educação e conscientização que poderiam amenizar seu acúmulo.

"O importante é não largar sujeira, frasco, garrafa, plástico, papel. As vezes aqui a gente passa por cima, mas o turista presta atenção e não gosta, então a gente sempre toma cuidado com esse negócio de lixo porque isso é a coisa mais feia" (B 14).

Outro problema que preocupa é a qualidade das águas dos rios, principalmente o Rio Caraíva, que já aponta índices de contaminação, impedindo o seu uso direto pelos comunitários e sendo vetor de doenças contagiosas.

"A gente não tem mais aquela vegetação toda... O que a gente pode fazer para recuperar? O rio, na minha época de criança, tinha muito peixe, e o mangue estava cheio de guaiamum. Hoje a gente não vê mais nem toca..." (V 8).

\title{
Questão fundiária e disputa por território
}

A RESEX foi criada para os pescadores, devido às invasões desenfreadas dos barcos pesqueiros.

\begin{abstract}
"Pescadores daqui não podiam pescar; depois da criação da RESEX os barcos de fora foram afastados, mas hoje ainda vem alguns" (X 6).
\end{abstract}

A disputa pelo território é uma realidade e está presente no discurso dos comunitários. Na Associação de Cumuruxatiba, por exemplo, há cadastrados 150 pescadores, muitos dos quais já venderam suas casas de beira de praia em condições muitos desfavoráveis e hoje moram nos morros. Atualmente os comunitários estão lutando para conseguir um terreno na beira da praia para a construção de um lugar para apoio aos pescadores, pois esta região já está toda tomada por barracas e pousadas.

Os donos das barracas de praia também não compram os peixes nas comunidades locais, e desta forma não contribuem com a geração de renda para os extrativistas. Apesar da praia ser considerada área de amortecimento da RESEX, os pescadores sequer têm o direito de puxar o bote para areia, pois ficaram isolados pelos grandes fazendeiros que compraram os terrenos na beira-mar. 
"Não só os indígenas, mas todas as populações tradicionais são empurradas para os morros. É difícil resistir em frente ao poder econômico dos ricos. As pessoas venderam realmente por falta de saída... É difícil ter canoa em beira de praia por causa do dono da barraca não deixar..." (X 7)

Os comunitários, principalmente os membros das aldeias indígenas, conhecem seus direitos e lutam pelo seu território, principalmente em buscar do reconhecimento das questões fundiárias. Houve narrativas de enfrentamentos com fazendeiros sobre disputa de áreas na beira da praia.

\begin{abstract}
"As pessoas que vem de fora tem que respeitar! Quiseram comprar minha terra com carro, boi, e eu não me vendo! Estou sobrevivendo do mar; minha luta é muito grande e tenho passado muita violência com pessoas de fora, com pessoas que estão querendo me engambelar para pegar a nossa terra" (X 4).
\end{abstract}

Segundo o depoimento de uma das lideranças, antes da RESEX havia mais de 200 barcos de fora, vindos de Pernambuco, Rio de Janeiro, Espírito Santo e Fortaleza. Agora aparecem alguns barcos, mas são barcos invasores que não permanecem muito tempo. Atualmente, a disputa de espaço ocorre entre os próprios comunitários, mas é uma disputa harmônica, que sempre existiu, diz ele. E continua esclarecendo que a maior preocupação que ainda resta é que a área terrestre da RESEX seja também demarcada, pois isso é condição para a garantia da permanência desse povo nesse território.

"Queremos um território demarcado pra as futuras gerações; a gente vive da terra e vive do mar; a gente quer um território garantido por lei" (B 3).

Um dos dilemas mais sérios e mencionados nas 3 oficinas, se refere à obstrução do acesso à Barra do Cahy após a implantação de uma cancela/portão na praia, construída por proprietários particulares e que impede a livre passagem dos comunitários, inclusive para levar turistas a este importante atrativo importante (história e natureza).

\title{
Desunião dos comunitários e individualismo nas relações de trabalho
}

Os comunitários relatam que houve muitas mudanças com a chegada do turismo na RESEX Corumbau, pois a atividade promoveu a entrada de muitas pessoas no território. O fluxo de turismo oriundo de Caraíva para Corumbau cresceu bastante, principalmente daquele tipo de turista que vem apenas passar o dia e retornar. Dentre outros impactos perceptíveis, um dos mais citados diz respeito à desunião e distanciamento crescente entre os extrativistas. Eis alguns trechos que demonstram esse problema: 
"Hoje, não é mais como era; cada um 'toca' uma parte. [...] Sempre que eu posso eu ajudo, mas as vezes não, porque não merece; cansa muito; [...] o turismo trouxe um dinheirinho, as pousadas movimentam, mas a união não é como era antes" (X 1).

Grande parte da comunidade presta serviços aos donos de empreendimentos turísticos e trabalha como empregados, sem tempo para se dedicar as suas tradições. Segundo a fala de uma jovem comunitária, o Turismo que vigora na região está muito atrelado ao modelo predatório do capitalismo, que estimula $o$ individualismo e a competição, promovendo também desequilíbrio ambiental.

"Antigamente a gente vivia só entre as famílias e hoje não; a falta de consciência do nativo de não valorizar o que tem, deixa o que vem "de fora" interferir no que é do nativo de modo que o nativo passa a depender daquele que Ihe explora" (V 8).

Antes, o que faziam era de modo mais coletivo, como a fabricação de farinha, atividade que era promovida por um rodízio de famílias, uma de cada vez. Em Curuípe, o peixe era dividido para toda a família, segundo um depoimento, mas a chegada do turismo trouxe o aumento do individualismo. Muitas outras atividades, como, por exemplo, o "rela" - construção coletiva das casas em mutirão -, já não são mais realizadas.

A Comunidade do Bujigão, aparentemente, constitui uma exceção quanto a esse aspecto. Os depoimentos revelam que lá o espírito de solidariedade e coletividade estão mais presentes, em contraposição aos relatos de individualismo, mais comumente relatados em outras comunidades da RESEX. A comunidade trabalha no transporte com buggys fazendo o trajeto de Caraíva a Corumbau, até a beira do rio e a travessia de canoa para a chegada a Corumbau. O sistema de rodízio entre os trabalhadores da travessia de canoa (entre Bujigão e Corumbau) permite uma melhor partição dos recursos arrecadados. Além disso, a Associação dos bugueiros também organiza uma economia mais solidária entre seus participantes.

\begin{abstract}
"A gente faz tudo no coletivo; o que um fez tem que dar para a comunidade toda. [...] No final do dia o que foi arrecadado com as travessias é dividido com todo mundo e assim dá oportunidade para todas as famílias e para quem quiser ir na travessia vai; com a associação, hoje tudo é no coletivo também" (B1).
\end{abstract}

No entanto, uma das queixas de alguns comunitários de Corumbau (e de Cumuruxatiba também) é que os próprios bugueiros, às vezes passam pelos restaurantes dos comunitários, mas só levam os turistas para se alimentarem em alguns poucos restaurantes, e sempre os mesmos, promovendo a desunião entre os extrativistas. 
" $E$ isso acontece muito aqui: o turista vem para beneficiar uma pessoa só ou duas pessoas só; isso não é Ecoturismo de Base Comunitária; então a gente tem que visar para se organizar para que isso não venha acontecer. Mas isso também depende dos próprios moradores e donos de restaurante daqui” (B 2).

Seria necessário a constituição de uma rede mais solidária, formada por todas as comunidades, cada uma tendo um papel e agindo como um organismo conectado para beneficiar a todos de forma direta e indireta.

\begin{abstract}
"A parte mais difícil é deixar de pensar só em você e começar a pensar no coletivo; deixar de ganhar um pouquinho mais e dar um pouquinho para o parceiro do lado. Como nós vamos fazer para todo mundo ganhar?” (B 4).
\end{abstract}

Percebe-se que algumas localidades estão mais afetadas pela desunião e individualismo do que outras. Em Xandó, outra comunidade próxima, há pequeno grupo que ainda faz atividades de forma coletiva, mas, segundo um depoimento, o turismo em Caraíva está se espalhando tão rápido que os comunitários estão deixando a essência de sua humanidade de lado.

"Não é o turista; somos nós que estamos abandonando as coisas que a gente praticava para dar atenção ao turista, para buscar mais renda. O turista ele tem que vir e se adaptar ao que a comunidade tem para oferecer para ele. Talvez a comunidade não possa oferecer para ele um chalé luxuoso, e se ele quer aquilo acho que ele está procurando no lugar errado (V 9).

O Centro Cultural Porto do Boi, organização cultural de um grupo de indígenas existente na região da comunidade de Barra Velha, ao lado de Caraíva, atualmente, recebe um turismo étnico um pouco mais ordenadamente. São 15 famílias (cerca de 50 pessoas) que fazem o Awê, vendem artesanato típico e, com isso, promovem a cultura pataxó.

Vale ressaltar que, apesar dos moradores locais se autodenominarem "comunitários" e chamarem o lugar de "comunidade, não se pode afirmar que eles assim o sejam. Segundo Shore (1996, p.115), comunidade é "um dos conceitos mais vagos e evasivos em ciência social", considerando que o que une uma comunidade pode ser "[...] um estado de espírito - um sentimento de comunidade" e não apenas a moradia numa localidade. Essa problemática mostra-se no diagnóstico que reúne grupos tão diferentes como moradores nativos (extrativistas tradicionais), povos indígenas (Pataxó), moradores que chegaram no início das atividades de turismo há mais de quatro décadas atrás e atores externos que parecem ter mostrado um protagonismo localmente. Em Caraíva apenas 5 famílias são nativas da região. Por esse motivo, de certa forma, não é surpreendente o relato de "desunião" e "individualismo" entre os "comunitários" na vida cotidiana, fato que não se evidenciou nas oficinas pela sua característica intrínseca, uma vez que as pessoas que se pronunciaram sempre o fizeram perante o grupo e há relações de 
poder que permeiam os eventos, e as rodas de conversa não permitem captar estas sutilezas. Para confrontar as "percepções" apreendidas nas oficinas, seria necessário a realização de entrevista individualizadas, pois há diferença de pronunciamento em grupo e fora dele, mas isso não foi possível no âmbito deste estudo.

\section{“Invasão” de empreendedores e visitantes externos às comunidades}

Os comunitários afirmaram que, há 15 anos, não havia o turismo que se observa na RESEX Corumbau. Naquele tempo, só se abriam restaurantes no verão, pois no inverno não havia nenhum movimento. Atualmente se observa turismo o ano todo, o que proporciona uma série de oportunidades de negócios, principalmente referente às atividades de mergulho.

No chamado Turismo de Scuba que vem sendo oferecido por comunitários em Corumbau, por exemplo, normalmente o visitante tem muito dinheiro e paga caro para mergulhar nos recifes da RESEX. Segundo um depoimento, esta prática tem potencial de ganhar mais visibilidade e de atrair mais turistas, gerando mais renda.

"esses caras do mergulho viajam o mundo todo então conhecem muita gente e o que vai acontecer? Vai trazer mais turismo, mais gente pra cá. Isso é bem importante" (B 12).

O modelo de turismo praticado em Caraíva, por exemplo, se aproxima muito do Turismo de Massa, já observado em Porto Seguro, Trancoso e Arraial d'Ajuda. Tal prática tem preocupado muitos os moradores, pois esse tipo de turismo traz embutido hábitos e comportamentos indesejados e que provocam impactos culturais e no meio ambiente.

"Temos que começar a agir! O turismo está crescendo muito; antes era contado as pessoas que vinham de fora. Hoje está difícil, a gente vê aqui mais gente de fora do que gente de Caraíva preocupado em aprender e tentar mudar" (V 3).

O acúmulo de lixo, que precisa ser removido da Vila de Caraíva de barco, também é outro fator de impacto citado pelos moradores, que relatam que os turistas fazem churrascos e pic-nics nas praias, sem se preocupar com a limpeza.

\footnotetext{
"esses locais que recebem o turismo, principalmente em Caraíva onde a maioria são empresários, o ideal seria se não pensassem apenas no dinheiro, mas também com os impactos gerados no meio ambiente: recifes, o lixo, etc. estava tendo muito turismo de massa nos recifes e tem que ter o controle sobre isso" (V 1)
}

Essa ocupação massiva da orla da praia pelos turistas também impacta a desova das tartarugas marinhas. Os comunitários, principalmente de Curuípe e Caraíva, manifestaram necessidade de se realizarem estudos sobre a capacidade de carga para o turismo. 

RESEX.

Outro ponto de destaque é a avistagem de baleias, um dos atrativos da

"Divulgando lá em São Paulo que vai ver baleia, esse turista vai precisar se hospedar, ir ao mercadinho, vai comer no restaurante; então vai colocar o dinheiro para circular aqui" (B 4).

A ocupação do território por empreendedores externos às comunidades é não só notória, mas motivo de muita preocupação e queixas para os locais. A cada novo estabelecimento comercial "de fora" que chega, novos impactos sociais se agravam como o aumento do custo de vida e a gentrificação. A concorrência desigual faz com que os membros das comunidades abandonem seus próprios negócios para trabalharem como empregados em pousadas e restaurantes.

\begin{abstract}
"A gente deixa a questão tradicional de lado porque pousada, restaurante de fora engole a gente; quem é o pescador que tem essa barraquinha na praia para concorrer com restaurante refinado? Quem é a gente pra alugar nossa casinha que é uma casinha simples para concorrer com pousada no TripAdvisor com ar condicionado?" (B 8).
\end{abstract}

Em Corumbau, conforme foi aumentando o número de turistas, os empreendimentos foram crescendo, justamente devido ao potencial do turismo local. Nas comunidades já há pessoas que têm alguma atividade (pesca, criação de galinha, marmitex).

\footnotetext{
"acredito que o turista chegando o comunitário vai pensar: eu vou colocar uma bodega aqui, eu vou vender isso aqui... E não é só para o turista que vem de fora não... Até mesmo para nós aqui. De repente em Corumbau falta uma pizza, daí um companheiro faz uma pizza, sabe?" (X 12).
}

Em Caraíva, apenas 5 famílias são nativas da região, e o restante veio de fora. Houve muitas pessoas que chegaram há 20 anos e lá permanecem se entrosando com os nativos. No entanto, mais recentemente, tem havido muito arrendamento de propriedades para a exploração do turismo. Em Curuípe, por exemplo, há casas para locação, pousadas, restaurantes, todos de pessoas não nativas ou colocadas para arrendamento pelos comunitários, que acabam, assim, sublocando seu patrimônio.

\footnotetext{
"Tudo isso que está acontecendo é culpa nossa; eu nasci e fui criado em Caraíva; conheço as tradições e era tudo muito diferente. Era todo mundo nativo e passado o tempo o povo começou a se deixar levar pela ilusão do dinheiro e acaba virando isso que a gente tá vendo aqui... Seria ótimo que as pessoas tivessem consciência que o arrendamento deve ser por um período determinado para ganhar o recurso para conseguir o objetivo" (V 7).
} 
Na voz de vários comunitários, a valorização do território, do espaço, é fundamental para o resgate da força da comunidade, que precisaria parar de vender ou alugar seu imóvel e permanecer no território. Eles reconhecem que, se os nativos buscassem alternativas e conhecimento sobre como receber o turista de forma mais adequada, conseguiriam sua subsistência de modo mais sustentável.

O turismo trouxe modificações e a até morte de hábitos culturais locais. Em Caraíva, por exemplo, um condomínio secou uma bica que era um atrativo da comunidade. Em Curuípe observou-se um desmatamento de uma área de mata ciliar para a construção de um estacionamento, e com alvará fornecido pela própria Prefeitura.

\section{Manutenção das culturas locais, com forte enraizamento e desejo de resgate e manutenção de modos de vida e cultura ancestrais}

O turismo está mudando muito a RESEX Corumbau, provocando uma perda de identidade para a região. Caraíva, por exemplo, é rotulada como um destino de Ecoturismo, mas poucos turistas que vão para lá sabem que estão visitando uma RESEX. Oriundos de Porto Seguro e atraídos por site de hospedagem e agências virtuais, principalmente, o Turismo de Massa tem promovido, inclusive, a mudança nas características arquitetônicas locais.

O impacto do ser humano na pesca em Corumbau preocupa seus moradores que não são imunes às mudanças ambientais. A criação da RESEX foi uma conquista muito grande, pois ela influencia diretamente na subsistência. Os extrativistas querem ter alternativa de geração de renda com o turismo, pois, na opinião deles, este traz benefício tanto para as comunidades quanto para o mundo inteiro.

"as pessoas acham que a gente escolhe uma vida mais simples, como se a gente não precisasse ganhar dinheiro então acho que a gente precisa saber como ganhar dinheiro, pois somos as pessoas que querem preservar o meio ambiente então essas pessoas precisam se fortalecer para impedir que outras pessoas que tem a cabeça de ganhar dinheiro e passar por cima de todo o meio ambiente" (B 3).

$\mathrm{Na}$ RESEX como um todo há uma diversidade muito grande para a prática do Ecoturismo de Base Comunitária e do Etnoturismo, voltado para conhecer a história dos povos locais,

\section{"até mesmo para terem um outro olhar diferente do que é passado da gente; essa visão europeia de que o índio é preguiçoso" (B 3).}

Há uma iniciativa de reativação de uma ONG local em Cumuruxatiba que já existia, o NemaCumuru, que fazia o trabalho de proteção do Rio Barrinha e que foi transformado no Instituto Caboclo para agregar esse trabalho a outros grupos culturais. A regularização jurídica do Instituto permitirá o desenvolvimento de projetos da capoeira, dança afro, curumim-batuque, o maracatiba, teatro, e equipes de vôlei. O Instituto Caboclo organiza no verão uma programação na Praça com a 
apresentação do resultado dos trabalhos (dança afro, curumim-batuque, Awê aldeias, por exemplo).

"A gente faz porque acredita e às vezes até esquece que precisamos ser remunerados com isso, de 'passar o chapéu' mesmo. A gente até perdia o espaço da praça. [...] Agora já conquistamos espaço no horário nobre no verão; grupos daqui são a prioridade nos horários melhores" (X 9).

Em Cumuruxatiba os moradores conseguiram que os eventos, agora anuais, gerem recursos para os que neles estão trabalhando. Em 2019 a maioria dos grupos "de fora" que quiseram se apresentar ali na praça perceberam que os grupos comunitários estavam organizados e vieram, bem respeitosamente, pedir autorização para poder entrar na programação.

"Todos que quiseram apresentar, vinham perguntar. É tudo questão de organização das comunidades. Vimos que estávamos perdendo espaço e aí demos uma acordada. Mas é difícil, porque temos que deixar e lado nossas atividades que nos sustentam e naquele momento ali na praça todo mundo está largando o que tem que fazer para estar lá” (X 9).

O ideal para o avanço dessas iniciativas seria a implantação de um turismo onde os coletivos de pescadores, indígenas, e demais coletivos pudessem resgatar suas referências e terem suas identidades valorizadas.

"Eu acho que isso é o mais rico daqui; porque todas essas pessoas têm toda essa raiz que é muito forte aqui, a indígena, negra, de pesca, de agricultura, acho que ser reconhecido nisso e ser valorizado nisso, seria o mais legal; pensando assim, acho que esse turismo de cada um ser seu próprio patrão e estar sendo reconhecido por isso cada vez mais" (X 7).

Em Cumuruxatiba, a festa de São Sebastião é uma das mais tradicionais, com seus rituais religiosos como a procissão e a "subida do mastro". No entanto, nos últimos anos, a grande presença de visitantes tem provocado ruídos indesejados nesses festejos. A prefeitura de Prado, inclusive, concede alvarás para comerciantes de fora se estabelecerem, e assim muitos deles colocam suas barracas na frente à associação de pescadores, não dando espaço para os nativos.

"A tradição foi engolida. Pousadeiro está barrando, porque atrapalha o turista. Sempre teve bandinha de madrugada. Uma coisa que é uma vez por ano. Está sendo quebrada por causa do turismo" (X 2). 
Na ponta do Corumbau há a festa comunitária de São Francisco de Assis. Todos os anos, depois da missa, há a tradição de "pegar no ramo" que é a responsabilidade que alguém organiza a festa. Há a procissão com os barcos enfeitados com balões, bandeirolas, que soltam fogos ao longo de um percurso de 3 $\mathrm{km}$, e todos embarcam quando eles chegam em terra.

"Todo ano, mês de outubro, a gente festeja com São Francisco que é o pai da natureza e amigo do Senhor. Então é a forma da gente aqui nesse paraíso que é Corumbau homenagearmos os nossos pescadores" (B 14).

Em Caraíva não é diferente, e a tradicional Festa de São Sebastião também está muito impactada pelo Turismo.

"Antes era bem melhor; antes tinham as festividades de São Sebastião que era a tradição da puxada de mastro na beira do rio, era a coisa mais linda... Mas isso diminuiu, acabou... [...] Agora é muito som alto... Este ano, graças a Deus, a comunidade se reuniu e fez com que diminuísse o barulho do som que não deixava ninguém dormir" (V 5).

Outra iniciativa de destaque em Cumuruxatiba é o grupo de mulheres, que faz várias reuniões e cursos de capacitação, como fabricação de licores, derivados da mandioca; festival de moqueca e outras comidas típicas da Bahia.

Para tentar valorizar a cultura da pesca, uma ideia que surgiu foi a implantação de um "selo" de pesca sustentável, uma vez que estão em uma reserva extrativista que impõe regras de manejo. A pesca ainda utiliza, primordialmente, técnicas tradicionais menos nocivas ao meio ambiente, sendo que a maior parte é para o sustento das famílias, e apenas o excedente vendido localmente. Os extrativistas não conseguem competir com a pesca industrial, que supre o mercado nas grandes cidades, mas com esse selo poderiam agregar valor ao pescado, seguindo uma tendência mundial na qual os produtos sustentáveis são valorizados. Os restaurantes locais que venderem o peixe pescado na RESEX poderão justificar o preço mais alto, pois estariam colaborando com a proteção do meio ambiente.

"para se dar valor ao peixe o camarada tem que pescar. Hoje trabalhamos o peixe na nossa própria cozinha, fornecendo refeição. Assim se agrega valor ao trabalho e ao pescado. $O$ pescador tem que aprender a valorizar a própria família. Não podemos perder a nossa cultura da pesca" (B 10).

Em Bujigão, a luta da comunidade teve início com a questão da melhoria da estrada que leva àquele local, pois antes havia muita dificuldade de acesso não só para o turista chegar ali, mas para os próprios comunitários. A construção dessa estrada melhorou a vida dos comunitários, pois facilitou a entrada de ônibus, buggys e fomentou o transporte dos turistas de Caraíva até lá. Há comunitários que já possuem seu transporte próprio para conduzir o turista, além de outros que abriram bares para vender comidas e bebidas, bem como quiosques com artesanato. 
"Não está que nem em Corumbau, mas a gente acaba fazendo umas estratégias para levar o turista num passeio de barco a remo, oferece um caranguejo, oferece uma ostra para quem se interessa; então essas são as atividades que a gente faz... Com uma canoinha a remo dá para levar o turista até o coral. $A$ gente com o turista vai melhorando a situação da gente. (B 11).

"Nossa comunidade é pequena, tem 84 pessoas, mas então aí já ajuda todo mundo. [...] Aí o turista vem e entra na sua casa e vê como que é... a gente fica até com vergonha, né? O turista entra lá e a casa da gente, é de taquara, e a gente até esconde eu fico com vergonha; mas o turista entra lá e acha bonito; porque é a cultura da gente que ele quer entender" (B 11).

As comunidades da RESEX podem valorizar a narração da história do lugar através de visitas guiadas, pois isso sensibilizaria muito os turistas. Tal atividade geraria pertencimento, pois a partir da compreensão e da valorização do território, há a promoção da valorização da cultura, e isso agregaria valor à experiência do turista. Normalmente quem conta as histórias são os nativos mais experientes, que durante os passeios explicam a história do local.

Em Barra Velha o turismo é ainda muito pouco explorado (existe apenas uma área de camping), mas há um desejo dos moradores de promover mais o turismo para a comunidade. Lá existem muitas famílias de artesões que hoje precisam caminhar até Caraíva ou Corumbau, às vezes sem condições de saúde, para vender seu artesanato e por baixo custo para atravessadores, a maioria vindo de outros Estados. Alternativas possíveis seriam a criação de feiras e eventos na própria aldeia para a venda direta desses produtos.

Os moradores das aldeias indígenas de Cumuruxatiba (Tibá, Pequi, Cahy, Alegria Nova, Gurita) são todos da etnia Pataxó. A área ainda não está demarcada (há somente o Relatório Circunstanciado de Identificação e Delimitação - RCID). O que está fortalecendo as aldeias em Cumuruxatiba é o acordo de gestão compartilhada com o Parque do Descobrimento, de modo que assim os comunitários estão tentando preservar a natureza e sua cultura para trabalhar com turismo. As escolas indígenas não ensinam apenas as matérias tradicionais, mas as crianças têm ensino da cultura indígena e aprendem a atividade da pesca.

"se você sentar com elas, elas vão sabem fazer um ritual; então, quando a gente se organizar para a atividade do turismo, o turista vai poder ver que a gente já está se preocupando para que as novas gerações não percam e valorizem a cultura local" (B 12)

A questão do pertencimento e da territorialidade é muito importante, pois quando os comunitários se sentem ligados ao seu território, acabam valorizando-o. O que os torna diferentes, é a sua cultura. 
"Então a gente precisa ter o entendimento do quanto isso é importante; e não é importante para o turista que vem, é importante pra nós; o turista vem passar o dia, o mês a semana e vai embora; nós é que temos que ter esse espírito de pertencimento, de valorizar o nosso território. [...] Então a gente tem que começar a valorizar o que é nosso, porque, quando a gente faz isso, também começa a agregar valor e aí sim você vai ter uma contextualização e uma complexidade das coisas" (B 3).

A praia de Curuípe é um exemplo do impacto do turismo com a chegada de visitantes. Ali estava localizada a Fazenda Curuípe, mas a visita de um exgovernador de São Paulo redundou na construção de uma pousada chamada Porto Espelho. Desde então, todos passaram a se referir ao local como "Praia do Espelho". Para os comunitários locais, houve uma significativa perda de identidade, uma vez que ninguém mais encontra "Praia do Curuípe" nos mecanismos de busca da internet.

\begin{abstract}
"Porque o cara tem uma pousada que comporta 20/30 pessoas ele coloca um batidão que é hit que vem de lá em São Paulo, ele implanta uma arquitetura que não tem nada a ver, ele coloca um muro onde antes não existia. Antes a gente pegava fruta do quintal de vovó, no quintal do vizinho. Então você está na sua casa e tem que pedir licença para passar no seu próprio quintal porque o cara é gringo, vem de não sei onde e não quer ver sua cara, mas quer te obrigar a engolir a cultura dele, a ouvir a música dele, a comer a comida dele. Então isso eu falo que magoa muito" (V 6).
\end{abstract}

\title{
Fraqueza nos arranjos institucionais formais
}

Durante as oficinas, foram apontadas por alguns comunitários as dificuldades de implementação de ações coletivas. Os conteúdos trabalhados em reuniões de capacitação encontram barreiras culturais para se tornarem realidade, mesmo quando se fala em Turismo. Já houve iniciativas de intercâmbio e, cerca de 10 a 12 anos atrás, uma série de cursos, estudos e planos que foram propostos, mas nunca saíram do papel.

Alguns comunitários trouxeram a questão da regularização jurídica das associações locais, como uma necessidade premente para a implantação do Ecoturismo de Base Comunitária e demais atividades já realizadas.

Em Cumuruxatiba houve uma luta coletiva pelo espaço da Associação dos Pescadores. Eles conseguiram o terreno, projetos de aquisição de freezers para os pescadores, computador e, com a ajuda da comunidade e de comerciantes locais parceiros, foi construído o prédio próprio. Hoje desenvolvem projetos com grupo de mulheres, de jovens, tentando se organizar cada vez melhor.

Em Bujigão há uma associação de pescadores e um conjunto de canoeiros, ainda não regularizado como associação. São dois grupos na travessia que trabalham de modo a ninguém ganhar mais do que os outros. 
"Trabalha igual, né? Então aí trabalha todo mundo em conjunto. Se é 20 pessoas, aí todo mundo trabalha. Então é uma coisa que favorece todo mundo. As vezes chega o turista e a gente oferece uma água de coco, uma ostra, um peixe assado, peixe frito... Então é todo mundo trabalhando para melhorar" (B 9).

Há nativos que acham que a RESEX é uma Unidade de Conservação que veio para atrapalhar suas vidas, e outros que entendem a sua criação como uma oportunidade de proteger o modo de vida e a subsistência das populações tradicionais pesqueiras, pois tem como missão a proteção do meio ambiente.

\begin{abstract}
"Tem gente que em vez de elogiar e participar das reuniões, só vem para criticar. A gente que está por dentro da situação, que procura inovar, tem que começar a se organizar melhor, utilizar as leis que existem para regulamentar perante as Prefeituras, incentivar, como você vender seu produto, para quem comprar deixar para o tradicional etc." (B11).
\end{abstract}

Em Cumuruxatiba existe uma Associação de turismo (CumuruTur), mas esta congrega apenas os pousadeiros e de restaurantes que são de fora, e os nativos não participam. Eles decidem tudo e articulam com a Prefeitura. Todo ano produzem um mapa (pago) onde são divulgadas as pousadas e restaurantes, mas os estabelecimentos dos nativos não são incluídos nesse mapa, pois os nativos não têm dinheiro para pagar divulgação. Uma das propostas que surgiu nas oficinas foi a elaboração de um mapa com os estabelecimentos, pousadas, barracas de praia, hospedagem e restaurantes de nativos e também das festas tradicionais, bem como falando sobre a RESEX, o seu papel na luta pela preservação do território e meios de vida das populações tradicionais e a luta dos comunitários para a permanência no território.

No festival gastronômico de Cumuruxatiba, os nativos também têm pouco ou nenhum espaço, pois o evento é articulado pelos "de fora", que têm dinheiro. Uma sugestão dada por um comunitário na oficina foi que os extrativistas poderiam abraçar esse evento e se envolver mais com ele.

"Os participantes da associação, que tem uma taxa alta, usufruem de todas as atividades da terra, botam só quem quer ou quem tem dinheiro para pagar a divulgação e isso faz com que os nativos fiquem invisibilizados" (X 2).

\title{
Potencialidade de parcerias com outros segmentos
}

A RESEX Corumbau tem potencialidade para estabelecer uma grande quantidade de parcerias com diferentes segmentos, desde pousadeiros, donos de restaurante, operadoras de turismo - incluindo atividades de mergulho -, representantes de outras Unidades de Conservação, pesquisadores de universidades etc., desde que algumas dificuldades sejam vencidas para a composição de redes de trabalho coletivo, incluindo acesso à recursos financeiros. 
Em Cumuruxatiba há a necessidade de se fortalecer institucionalmente as associações locais perante o poder público, como por exemplo a busca de apoio junto a Prefeitura de Prado para a obtenção de alvará para a montagem das barracas nos locais mais importantes, para dar prioridade aos comunitários no fornecimento dos produtos, e para retomar os espaços das festas tradicionais.

Algumas aldeias estão trabalhando na elaboração de um projeto para concorrer a recursos oriundos do "Bahia Produtiva", uma iniciativa estadual executada pela Companhia de Desenvolvimento e Ação Regional com o intuito de financiar projetos de inclusão socioprodutiva das comunidades tradicionais em Unidades de Conservação da Bahia. A ideia é que as aldeias façam um intercâmbio para receber turistas na lógica do Ecoturismo de Base Comunitária. Cada aldeia fará um pacote para oferecer ao turismo. Esse edital é específico para roteiro interaldeias dos indígenas para oferecimento de turismo étnico.

Outra ideia de parceria que surgiu nas oficinas foi o estabelecimento de parcerias com cursos universitários de Turismo para fazer pesquisas sobre o perfil do turista que visita a RESEX e para levantar o potencial do TBC no local.

Outra possibilidade sugerida seria de desenvolver um roteiro turístico integrado de forma sustentável, afinal há os dois parques que estão muito próximos à RESEX Corumbau (Monte Pascoal e do Descobrimento), sendo importante que as comunidades se organizassem e conversassem com os gestores. Além disso, há outras três RESEX, uma próxima a outra, com as quais é possível o estabelecimento de uma rede de apoio única ou um roteiro mais amplo.

"A gente precisa conversar mais, pois a gente está muito distante. Estamos tão perto e tão distantes... É muito loucura a chegada aqui, devido à dificuldade da logística, mas vamos nos comunicar mais e estar mais presentes dentro das outras RESEX. Acho que isso é muito importante para nós, comunitários" (B 13).

\section{Atrativos apontados pelos comunitários}

Os principais atrativos da RESEX, na opinião dos comunitários, foram levantados durante as oficinas, e têm ainda um caráter exploratório e não foi muito exaustivo. No entanto, já foram revelados alguns atrativos mais evidentes da RESEX:

- Beleza cênica das praias, muitas delas com falésias e vegetação nativa;

- Águas mornas do mar da região;

- Mergulho livre e autônomo nos recifes de corais;

- Avistagem de baleias migratórias em algumas épocas do ano;

- Manguezais preservados com sua fauna e flora características;

- Passeios em embarcações pelos rios, de barco, caiaque e stand up;

- Passeios em embarcações pelo mar, de onde se pode avistar o Monte Pascoal; 
- Gastronomia local;

- Arte e artesanato indígena e de outras comunidades;

- Aspectos históricos referentes a chegada dos portugueses no Brasil; Fabricação de produtos locais, como o óleo de coco, a farinha de mandioca, essência de almescar, plantas medicinais, dentre outros;

- Observação de cavalos marinhos e outras espécies de peixes;

- Manifestações culturais, como a Festa do Mastro de São Sebastião, o Awê, as cirandas de roda, danças e músicas Pataxó, e os festivais de música nativa;

- Farol e a Ponta do Corumbau;

- Diversidade étnica e cultural e a hospitalidade do povo local;

- Acompanhamento das diversas etapas da pesca artesanal;

- Idiomas locais, com destaque para o Patxiohã;

- Aldeias Pataxó; e

- Trilhas pelos Parques Nacionais do entorno da RESEX.

O Terceiro bloco das Oficinas teve como objetivo visitar alguns desses atrativos juntamente com os comunitários, que fizeram diversos relatos sobre os aspectos mais importantes de cada um, em uma simulação prática do que seria o protótipo de um roteiro turístico. Essa atividade, que foi realizada nas três oficinas, teve e a duração de 4 horas cada uma, e resultou na gravação de um acervo de imagens e informações que posteriormente foi editada em um curta metragem no formato de vídeo. Todos os depoimentos gravados também foram arquivados para eventual uso futuro pelos comunitários e gestores da RESEX.

\section{Considerações finais}

Em linhas gerais, a primeira possibilidade apresentada por Maldonado (2009) no Quadro 1 (autogestão do negócio turístico), refere-se ao que se pensaria como cenário ideal para o TBC, pois a comunidade possui o poder decisório sobre os rumos da atividade. A quinta (trabalho assalariado para operários) seria a maneira mais passiva, sendo relevante para algumas famílias, mas de pouca abrangência em termos de comunidade. Dentro do que se pode observar da realidade da RESEX Corumbau, as comunidades, grosso modo, poderiam estar enquadradas na quinta ou sexta (forma híbrida) possibilidades dessa classificação de Maldonado (2009). Longe, portanto, ainda, da condição ideal para o TBC (primeira possibilidade).

Vale lembrar que essa proposta de Maldonado (2009) não determina que haja uma espécie de escada, onde a comunidade precisaria passar por cada etapa até a autogestão. Pode-se compreendê-la como possíveis arranjos que, inclusive podem ter natureza múltipla (formas híbridas) e que são influenciadas pela comunidade, pelos agentes externos e pelos próprios turistas. O que o quadro nos mostra é que as experiências de TBC não são homogêneas; elas possuem características próprias e diversas. Essa nos parece ser a realidade da RESEX Corumbau. 
É importante ressaltar que o TBC não é um segmento do turismo, como o é o Ecoturismo, por exemplo. Ele é uma forma de organização do turismo pautada nos princípios de sustentabilidade, mas que tem como bojo principal o protagonismo da comunidade no seu desenvolvimento e não apenas no contato com os turistas, como ocorre em algumas atividades, inclusive de Ecoturismo ou de outros segmentos.

Na RESEX Corumbau já existem iniciativas de um tipo de turismo que pode proporcionar experiências associadas a alguns segmentos da atividade turísticas. Pode-se dizer que, no caso do mergulho nos recifes de coral, por exemplo, há um "Ecoturismo de Base Comunitária", onde o turista tem buscado o contato com a natureza, mediante uma atitude responsável, porém com o diferencial de ter a comunidade receptora protagonizando a organização.

Essa característica fica mais clara se pensarmos que, como também ocorre na RESEX Corumbau, agências de turismo têm promovido visitas e o contato do turista com comunidades sem envolver as mesmas no planejamento da atividade $e$ na participação da maior parte dos benefícios. Neste caso, o que assistimos, é o turismo convencional, agenciado, até mesmo de massa, mas não se trata de base comunitária.

O que falta, no caso do turismo na RESEX Corumbau, portanto, é uma real organização por parte das comunidades para decidirem se e em que termos ocorrerá o contato com o turista, se haverá parceria com uma agência e de que modo os lucros e responsabilidades serão repartidos, bem como quais aspectos de sua cultura e ambiente serão proporcionados ao turista conhecer. Ou seja, se os comunitários da RESEX Corumbau saírem de uma condição de "atrativo" para serem planejadores da atividade, neste caso poder-se-á considerar que o turismo ali praticado ganhará elementos caracterizadores do Ecoturismo de Base Comunitária.

Essa transição ainda é necessária, afinal o que determina que uma experiência seja de TBC não é a vinculação a um segmento específico do turismo ou a presença/ausência de uma agência de turismo ou de outro agente externo, como agentes públicos ou do terceiro setor, mas sim o grau de engajamento e de poder decisório de uma comunidade sobre a realização da atividade turística em seu território.

Diante dessa reflexão, outra questão interessante de ser abordada para a realidade da RESEX Corumbau, é que o turismo não deve competir nem, menos ainda, suplantar as atividades tradicionais que têm garantido a sobrevivência das comunidades, como é o caso da pesca artesanal. O TBC deve ser concebido como um complemento ao progresso econômico e ocupacional para potencializar e dinamizar essas atividades tradicionais que as comunidades já realizam com imensa sabedoria e maestria (MALDONADO, 2009).

Pode-se contrapor, aqui uma contradição entre uma visão otimista da "manutenção do modo de vida", da "cultura ancestral" e da "agricultura de subsistência", mas é necessário se fazer o apontamento da sua incompatibilidade com as exigências da vida cotidiana atual dos moradores locais, e, ainda mais, com um protagonismo dos comunitários na atividade turística, como mostram as seguintes frases: por um lado, "o turismo está mudando muito a RESEX Corumbau, provocando uma perda de identidade para a região"; por outro, "queremos ter uma alternativa de geração de renda com o 
turismo, pois, isso este nos traz benefícios". Essa contradição pode colocar em risco a aplicabilidade do TCB no contexto estudado.

A percepção do TBC como "tábua de salvação" pode gerar grandes frustrações no desenvolver da atividade por parte de comunidades, pois muitos comunitários podem abandonar suas atividades (pesca, lavoura, extrativismo) para dedicar-se ao turismo, porém sem obter o êxito esperado e, ainda, afastarem-se de seu modo tradicional de vida e reprodução, que são condições essenciais de sua existência.

Além disso, outro motivo que pode gerar esse sentimento ocorre quando se verifica o que Holanda (2016) chama de "empresarização" do TBC. Segundo a autora, ao buscar tornarem-se competitivas no mercado turístico, algumas comunidades se veem obrigadas a manter rotinas de profissionalização e de atividades administrativas e burocráticas pertinentes a esse tipo de empreitada, porém que as afastam do seu modo de viver tradicional, gerando insatisfação para elas.

Ou seja, no caso das comunidades da RESEX Corumbau, o TBC não deve ser sinônimo de transformar a comunidade em uma empresa. O modelo empresarial está voltado para o lucro financeiro e as comunidades, embora também queiram percebê-lo, possuem outras necessidades, como a de conexão com a natureza e com a sua cultura, aspectos estes que precisam ser tratados como prioritários por elas, pelos apoiadores externos da atividade e, principalmente, pelos turistas.

Diante disso, o TBC precisa ser pautado na compreensão do que é importante para a comunidade e para a sua manutenção enquanto tal, nisso embutidos seus valores e subjetividade. Uma comunidade não precisa necessariamente desenvolver o TBC mas, se decidir fazê-lo, é relevante refletir sobre esses diversos aspectos que o compõem, inclusive o melhor formato jurídico e de governança para o local.

Como resultado das análises realizadas propõe-se, neste estudo, para a continuidade do processo decisório sobre a pertinência, ou não, da implantação do TBC, alguns conceitos e indicadores, baseados em Ribeiro e Timóteo (2012), que correlacionam indicadores para entidades do terceiro setor para sua manutenção econômica que alicercem seus objetivos sociais, tal como as Associações existentes na RESEX Corumbau, que podem assumir a operação do roteiro de TBC. De modo mais objetivo, propomos como próximos passos:

1)Criar, no âmbito do Conselho Gestor da RESEX Corumbau, a Câmara Temática do Ecoturismo de Base Comunitária, com representantes de todas as comunidades e demais interessados na atividade;

2)Realizar um diagnóstico mais detalhado sobre as comunidades e associações interessadas e os atrativos existentes para a implementação de um Roteiro Piloto de TBC;

3)Estabelecer formas de governança, arranjos jurídicos (empresas, cooperativas, associações etc.) e instâncias de decisão sobre o TBC;

4)Promover intercâmbio das lideranças comunitárias locais com outras iniciativas e Redes de TBC existentes, principalmente as que já ocorrem em outras RESEX e UCs da Bahia; 
5)Criação de projeto de divulgação e comercialização do TBC na RESEX Corumbau;

6)A partir da organização existente em Bugigão, aperfeiçoar modelos de economia solidária, com e eventual criação de uma moeda social na RESEX Corumbau.

Uma fala emblemática de um comunitário surgida durante uma das oficinas afirmou: "o turista que vai para a RESEX quer encontrar algo similar a Trancoso e Arraial D'Ajuda, e isso espanta os nativos e faz o lugar ficar 'com cara de São Paulo". Essa fala demonstra, muito simbolicamente, o grau de interferência e desintegração que o turismo, como atividade indissociada do sistema capitalista vigente, exerce, tanto no ambiente, quanto na subjetividade das comunidades tradicionais da região. Portanto um caminho para se construir um turismo socialmente mais consciente e que contribuísse para a conservação dos modos de vida e saberes locais, seria trabalhar a união e empoderamento dos comunitários da RESEX Corumbau, de modo a fortalecer e valorizar suas tradições e cultura tão precisos, inclusive como atrativos potenciais para o turismo.

Como observação final, ante a realidade do turismo praticado em regiões próximas ou mesmo dentro da RESEX Corumbau, como em Porto Seguro e Prado, cabe alertar que o TBC pode se estabelecer como uma alternativa de "turismo dentro do turismo". Isto é, uma forma diferenciada de atividade turística que pode coexistir com a que já ocorre, desde que, para receber o qualificativo "base comunitária', consiga divulgar seu diferencial que pode ser trabalhado na perspectiva do marketing, com fins de alcançar um público específico, no caso o turista que almeja vivências autênticas com as comunidades e seu modo de vida tradicional. Com isso, a qualificação do turismo enquanto uma atividade de base comunitária, poderá promover o posicionamento do produto local na percepção do consumidor em potencial.

\section{Referências}

BACAL, S.S.; MIRANDA, S.M.A. Impacto do turismo nos núcleos receptores: necessidade de normalização. São Paulo: Hucitec, 1997.

CARVALHO, J.A.; KNOX, W. O mar não está para peixe: conflitos socioambientais na Reserva Extrativista Marinha do Corumbau. Anais da 29a Reunião Brasileira de Antropologia, Natal/RN, agosto de 2014.

ESPÍNOLA, R.; ANDRADE, M. Turismo em comunidades tradicionais: dilemas e perspectivas no município de Conde-PB. In: GONÇALVES, A.; RODRIGUES, L. (Org.). Políticas de turismo, ambiente e desenvolvimento. João Pessoa, PB: Ed. UFPB, 2015. (Vol. 3, Série Pesquisa Prodema).

FARIA, D.M.C.P. Impacto do turismo em um destino a partir da perspectiva da economia convencional e ecológica. Observatório de Inovação do Turismo Revista Acadêmica. Volume II - Número 3 . Setembro de 2007

FREITAS, T.P.; MATTOS, Y. Impactos culturais do turismo: contradições e paradoxos - estudo de caso com os Índios Pataxó de Porto Seguro e Santa Cruz de Cabrália BA. Revista Eletrônica de Turismo Cultural, v. 3, n. 1, p. 117-23, 2009. 
GRÜNEWALD, R.A. A Coroa Vermelha no imaginário indígena e brasileiro. Anais da 22a Reunião Brasileira de Antropologia. Fórum de Pesquisa 2: "O imaginário brasileiro". Brasília, 2000.

HOLANDA, L.A. Empresarização do turismo de base comunitária. Caderno Virtual de Turismo. Rio de Janeiro, v. 16, n. 2, p. 249-262, ago. 2016.

IRVING, M.A. Reinventando a reflexão sobre turismo de base comunitária: inovar é possível? In: BARTHOLO, R.; SANSOLO, D.G.; BURSZTYN, I. Turismo de Base Comunitária: diversidade de olhares e experiências brasileiras. Rio de Janeiro: Letra e Imagem, 2009. P. 108-121.

KASHIMOTO, E.M.; MARINHO, M.; RUSSEFF, I. Cultura, identidade e desenvolvimento local: conceitos e perspectivas para regiões em desenvolvimento. Interações: Revista Internacional de Desenvolvimento Local, Campo Grande, MS, v. 3, n. 4, p. 35-42, mar. 2002.

LOZADA, L. Serviços ecossistêmicos e interações com uma comunidade afrodescendente no Pacífico colombiano: dos riscos à proteção da biodiversidade. 2017. Dissertação (Mestrado em Desenvolvimento e Meio Ambiente) - Universidade Federal da Paraíba, João Pessoa, PB, 2017.

MALDONADO, C. O turismo rural comunitário na América Latina: gênesis, características e políticas. In: BARTHOLO, R.; SANSOLO, D.G.; BURSZTYN, I. Turismo de Base Comunitária: diversidade de olhares e experiências brasileiras. Rio de Janeiro: Letra e Imagem, 2009. P. 25-44.

RIBEIRO, L.M.; TIMÓTEO, A. A Adoção dos Controles Internos em uma Organização do Terceiro Setor como Sustentabilidade Econômica: Um Estudo de Caso em uma Associação de Minas Gerais. Revista Contemporânea de Contabilidade. UFSC, Florianópolis, v.9, n.17, p.61-82, 2012.

SANSOLO, D.G.; BURSZTYN, I. Turismo de base comunitária: pontencialidade no espaço rural brasileiro. In: BARTHOLO, R.; SANSOLO, D.G.; BURSZTYN, I. Turismo de Base Comunitária: diversidade de olhares e experiências brasileiras. Rio de Janeiro: Letra e Imagem, 2009. P. 142-161.

SCHORE, C. Comunidade. In: OUTWHAITE, W.; BOTTOMORE, T. Dicionário do Pensamento Social do século XX. Rio de Janeiro: Jorge Zahar Ed., 1996, p. 115117.

\section{Nota:}

${ }^{1}$ Denominamos como Ecoturismo de Base Comunitária o TBC que incorpora os princípios intrínsecos do Ecoturismo, notadamente a preocupação com a conservação de recursos naturais e a Educação Ambiental.

\section{Agradecimentos:}

Os autores agradecem às todos comunitários que participaram das oficinas (Comunidades de Bujigão, Curuípe, Caraíva, Veleiro, Barra Velha, Corumbau, Xandó, 2 Irmãos, Cumuruxatiba, Imbassuaba, Satu, Cahy, Tibá, Tawá, Atalaia e Puxim da Praia), bem como à Rosângela de Assis Nicolau, gestora da RESEX Corumbau, à analista ambiental Flávia Rossi de Morais, do ICMBio, e ao Fundo Brasileiro para a Biodiversidade (FunBio) que financiou o estudo por meio do Projeto Áreas Marinhas e Costeiras Protegidas - GEF-Mar. 
Zysman Neiman: Universidade Federal de São Paulo, Diadema, SP, Brasil. E-mail: zneiman@gmail.com

Link para o currículo Lattes: http://lattes.cnpq.br/6435341856481082

Juliana Maria de Barros-Freire: Universidade Federal de São Paulo, Diadema, SP, Brasil.

E-mail: juliana@barros-freire.adv.br

Link para o currículo Lattes: http://lattes.cnpq.br/1313465743146374

Data de submissão: 30 de janeiro de 2020.

Data de recebimento de correções: 16 de julho de 2020

Data do aceite: 16 de julho de 2020

Avaliado anonimamente 